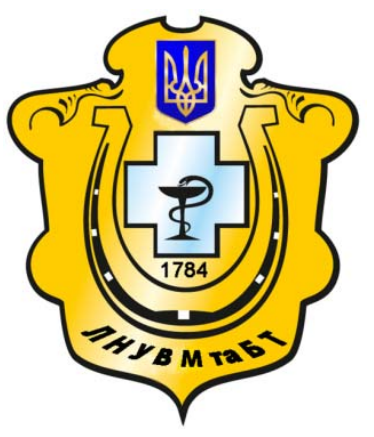

Науковий вісник Львівського національного університету ветеринарної медицини та біотехнологій імені С.3. Гжицького

Scientific Messenger of Lviv National University of Veterinary Medicine and Biotechnologies named after S.Z. Gzhytskyj

doi:10.15421/nvlvet7013

ISSN 2413-5550 print

ISSN 2518-1327 online

$\underline{\text { http://nvlvet.com.ua/ }}$

УДК: 639.37:663.63

\title{
Особливості використання біофільтрів з різними типами наповнювача в установках замкнутого водопостачання в аквакультурі
}

\author{
Н.С. Гриневич \\ gnatbc@mail.ru

\begin{abstract}
Білочерківський нациіональний аграрний університет, пл. Соборна, 8/1, м. Біла Церква, 09117, Украӥна
\end{abstract}

\begin{abstract}
Представлено огляд джерел літератури, які відображають особливості функціонування установок замкнутого водопостачання (УЗВ) в аквакультурі з використанням біофільтрів з різними типами наповнювача для очищення води. Висвітлено значення механічного та біологічного фільтрування для роботи УЗВ. Охарактеризовано перебіг біохімічних та мікробіологічних прочесів у біофільтрах за використання рухомих та нерухомих наповнювачів. Акиентується на необхідності денітрифікаиії для підтримання життєздатності мікрофлори біоплівки. Представлено основні чинники, які впливають на ефективність функиіонування індустріальних господарств з вирощування райдужної форелі. Обгрунтовано доијльність проведення щоденного моніторингу якості води в УЗВ задля запобігання епізоотіям та нітритним отруєнням вирощуваної риби. Наголошується, що ветеринарні заходи відповідно до встановленого діагнозу варто здійснювати у такий спосіб, щьоб, допомагаючи одному організму (райдужна форель), не зашкодити іншому (біоплівка наповнювача фільтраційного реактора). Робиться висновок про необхідність детальнішого дослідження складу, фізіологічних особливостей та ролі біоплівки як суміжного організму під час вирощування об'єктів аквакультури.

Ключові слова: райдужна форель, аквакультура, замкнута система водопостачання, механічний фільтр, біофільтр, біоплівка, рухомий і нерухомий наповнювач біофільтра, денітрифікаиія, турбулентність води.
\end{abstract}

\section{Особенности применения биофильтров с разными типами наполнителя в установках замкнутого водоснабжения в аквакультуре}

\author{
Н.Е. Гриневич \\ gnatbc@mail.ru
}

Белочерковский национальный аграрный университет, пл. Соборная, 8/1, г. Белая Церковь, 09117, Украина

\begin{abstract}
Представлен обзор источников литературы, отражающее особенности функиионирования установок замкнутого водоснабжения (УЗВ) в аквакультуре с использованием биофильтром с различными типами наполнителя для очистки воды. Освещены значения механического и биологического фильтрования для работы УЗВ. Характеризировано течение биохимических и микробиологических процессов в биофильтрах при использовании подвижных и неподвижных наполнителей. Акиентируется на необходимости денитрификации для поддержании життеспособности микрофлоры биопленки. Представлены основные факторы, которые влияют на эффективность функичионирования индустриальных хозяйств по выращиванию радужной форели. Обоснована целесообразность проведения ежедневного мониторинга качества воды в УЗВ для предотвращения эпизоотий и нитритных отравлений выращевоемой рыбы. Отмечается, что ветеринарные мероприятия в соответствии с установленным диагнозом следует осуществлять таким образом, чтобы, помогая одному организму (радужная форель), не навредить другому (биопленка наполнителя фильтрационного реактора). Делается вывод о необходимости более детального исследования состава, физиологических особенностей и роли биопленки как смежного организма во время выращивания объектов аквакультуры.

Ключевые слова: радужная форель, аквакультура, замкнутая система водоснабжения, механический фильтр, биофильтр, биопленка, подвижной и неподвижный наполнитель биофильтра, денитрификация, турбулентность воды.
\end{abstract}

Citation:

Grynevych, N. (2016). Features of bio filters with defferent types of filler plants in closed water acuaculture. Scientific Messenger LNUVMBT named after S.Z. Gzhytskyj, 18, 3(70), 57-61.

Scientific Messenger LNUVMBT named after S.Z. Gzhytskyj, 2016, vol. 18, no 3 (70) 


\title{
Features of bio filters with defferent types of filler plants in closed water acuaculture
}

\author{
N. Grynevych \\ gnatbc@mail.ru \\ Belotserkovskii national agrarian university, \\ Cathedral Pl., 8/1,Bila-Tserkva, 09117, Ukraine
}

\begin{abstract}
The review of literature sources that reflect the peculiarities of closed water systems (RAS) in aquaculture using bio filters with different types of filler for water cleaning. Deals with the importance of mechanical and biological filtration for RAS. Biochemical and microbiological processes inside the bio filters with movable and immovable fillers were deliberated. The attention on the need to maintain the viability of denitrification bio filters microflora. The basic factors that influence the efficiency of industrial enterprises with growing rainbow trout. The necessity of daily monitoring of water quality in RAS to prevent epizootic and nitrite poisoning grown fish. It is noted that veterinary measures in accordance with established diagnosis should be carried out in such a way that by helping one body (rainbow trout), does not affect the other (bio filters of the filtration filler). The conclusion about the need for more detailed study of the composition, physiological characteristics and biofilters role as a concomitant body during the growing aquaculture objects.
\end{abstract}

Key words: rainbow trout aquaculture, closed water system, mechanical filter, biofilter, biofilm, moving and stationary bio filters filler, denitrification, water turbulence.

\section{Вступ}

У сучасних умовах розвитку аквакультури актуальним $\epsilon$ розведення та вирощування риби та водних безхребетних у штучно створених контрольованих умовах з високим рівнем механізації та автоматизації технологічних процесів, а саме - в рибоводних установках із замкнутим циклом водопостачання (УЗВ).

У країнах СС екологічно чистою визнається лише та рибна продукція, яку вирощено в умовах установок замкнутого водопостачання. Масштаби розвитку цього напряму аквакультури на території у європейських країнах вражаючі (Alabaster, 1984). Прикладом може слугувати Польща, яка, зробивши на початку 90-х років минулого століття ставку на вирощування в УЗВ порційної форелі, зуміла за два десятиліття довести обсяги вирощування риби до 20 тис. т на рік і сформувати в СС стабільно функціонуючий споживчий ринок цього продукту (Asi and Relve, 1985). В Україні в умовах УЗВ вирощують в основному осетрових, тимчасом у центральних і південних районах країни перспективним $є$ вирощування в установках порційної форелі.

Під час планування вирощування форелі в УЗВ слід враховувати, що ця технологія потребує постійних витрат і вони значно вищі порівняно з видатками традиційних басейнових та садкових господарств. Зміни клімату і зменшення опадів, посушливі весни та літо спонукають власників рибницьких господарств до переходу на більш водоекономні програми вирощування риби (Bogdanova et al., 1988). Стосовно УЗВ зниження собівартості досягають у тому числі за рахунок удосконалення процесу очищення води 3 використанням механічної та біофільтрації.

Метою дослідження $\epsilon$ аналіз особливостей використання біофільтрів 3 різними типами наповнювача для очищення води в установках замкнутого водопостачання у прісноводній аквакультурі.

\section{Результати та їх обговорення}

Вирощування риби в УЗВ, незважаючи на високі витрати на їх створення та експлуатацію, належить до інтенсивної технології у промисловому рибництві. Виправданим в економічному сенсі $є$ використання таких видів риб, ціна на кінцеву продукцію яких дає змогу окупити вкладення в будівництво установки i витрати на іiі функціонування. Ще одним важливим чинником $є$ швидкість росту риби, відтак, ії собівартість. Перехід рибницького підприємства від дво- чи трирічного циклу вирощування риби до однорічного дасть змогу значно скоротити термін окупності коштів, вкладених у розбудову господарства. Не менш важливим $є$ також виживання риби на всіх етапах вирощування та іiі невибагливість до умов утримання, умов санітарії тощо (Asi and Relve, 1985; Bogdanova et al., 1988). Моніторинг вітчизняних господарств, що вирощують рибу за цією технологією, показує її ефективність,особливо у разі вирощування цінних видів риб у центральних та східних областях України.

Значення механічного та біологічного фільтрування для роботи УЗВ. Ця технологія базується на застосуванні механічних та біологічних фільтрів i може використовуватись для вирощування різних об'єктів аквакультури: риби, креветок, двостулкових молюсків та ін. Однак рециркуляційні технології застосовуються, головним чином, у рибництві (Zhezmer, 1988). Практика діяльності українських індустріальних рибницьких господарств показує, що такі технології використовують для вирощування осетрових, лососевих і зрідка сомових.

Механічний фільтр не спроможний затримати всі органічні речовини, крізь нього проходять найдрібніші частинки, а також розчинені неорганічні сполуки, зокрема, фосфатні та азотні. Фосфати зазвичай $є$ інертними речовинами без токсичних властивостей, тимчасом азот у формі вільного амоніаку є досить токсичним, однак завдяки мікроорганізмам біофільтру він перетворюється у нешкідливий нітрат. (Asi and Relve, 1985; Labbe et al., 2014). 
Для досягнення бажаної швидкості нітрифікації температура води в УЗВ повинна бути в межах $10-$ $35^{\circ} \mathrm{C}$, а рівень $\mathrm{pH}$ - від 7 до 8 (Hrustalev et al., 2013; Labbe et al., 2014). При цьому температура води залежить від виду риби, що вирощується, і встановлюється такою, щоб забезпечити оптимальні рівні росту риби, а не бажану швидкість нітрифікації..

3 огляду на те, що низькі рівні $\mathrm{pH}$ знижують ефективність біофільтрації (Hrustalev), а високе рН спричиняє поступове наростання кількості $\mathrm{NH}_{3}$, що збільшує токсичний ефект (Hrustaljov et al., 2013), важливо регулювати $\mathrm{pH}$ відповідно до ефективності біофільтра. Рекомендована межа $\mathrm{pH}$ знаходиться між 7,0 та 7,5.

Амоніак токсичний для риби, коли його кількість перевищує 0,02 мг/л води. Хоча низькі значення $\mathrm{pH}$ мінімізують небезпеку перевищення токсичного рівня амоніаку, для більш ефективної роботи біофільтра рибоводам рекомендують досягти рівня $\mathrm{pH}$ як найменше 7 (Titarev, 2005; Ponomarev, 2009).

Нітрити $\left(\mathrm{NO}_{2}^{-}\right)$, які утворюються в процесі нітрифікації, $\epsilon$ токсичними для риби за рівнів вище 2 мг/л. Ознакою отруєння ними риби, що знаходиться у замкнутій системі, $є$ хватання повітря (така клінічна картина характерна в основному для лососевих), незважаючи на достатню концентрацію кисню. За високих концентрацій нітрити через зябра потрапляють у кров, що перешкоджає поглинанню кисню.

Нітрати $€$ кінцевими продуктами процесу нітрифікації і хоча вважаються нешкідливими, їх великі кількості (більш ніж 100 мг/л) негативно позначаються на рості і розвитку риби та ефективності годівлі (Matishov et al., 2006; Kupinskij, 2007; Ponomarev, 2009).

За мінімальної подачі свіжої води в замкнуту систему нітрати накопичуються і можуть досягти дуже високих рівнів $(200-300$ мг/л). Для запобігання їх акумуляції слід збільшити додавання свіжої води, що сприятиме зменшенню концентрації цих сполук до безпечного рівня (Novozhenin et al., 1985; Ojsbojt, 1985). Тимчасом рециркуляційні системи спрямовані передусім на економію води. У таких випадках зниження нітратів можна досягти денітрифікацією. У нормальних умовах споживання води, що перевищує 300 л на кілограм використаного корму, денітрифікацію слід розглядати як обов'язкову операцію (OST 15.372-87).

Денітрифікація буває двох типів - асиміляторна і дисиміляторна. За асиміляторної денітрифікації нітрати відновлюються до амоніаку, який використовується як джерело азоту для побудови тіла мікроорганізмів. За дисиміляторної денітрифікації нітрати використовуються як окиснювачі органічних речовин замість молекулярного кисню, що забезпечує мікроорганізми необхідною енергією. Здатність до дисиміляторної денітрифікації мають тільки специфічні аеробні бактерії. Найпоширеніші денітрифікуючі мікроорганізми - бактерії роду Pseudomonas. До них належить велика гетерогенна група широко розповсюджених у біосфеpi мікроорганізмів, загальнобіологічна роль яких реалізується передусім у процесах мінералізації органічних сполук. Відтак, у процесі денітрифікації азот із води видаляється в атмосферу, тим самим знижуючи навантаження азоту на середовище існування риби. Для процесу денітрифікації необхідне джерело органіки (вуглекислота). 3 цією метою у денітрифікаційну камеру додають метанол. Зазвичай денітрифікація кожного кілограма нітрату потребуе 2,5 кг метанолу. У денітрифікаційну камеру вносять наповнювач для біофільтрації, проектний час перебування якого становить 2-4 год (Feofanov and Golosuj, 1986; Brajnballe, 2010).

Практика показує, що дуже часто нітритне отруєння риби діагностують як епізоотію. Для виключення останньої проводять бактеріологічні дослідження, які потребують певного часу, що перешкоджає вчасному виведенню риби із стану отруєння. 3 огляду на зазначене вище, у господарствах, що працюють за технологією замкнутого циклу водопостачання, рекомендують проводити щоденний моніторинг параметрів води.

Роль і види наповнювачів біофільтрів для функиіонування УЗВ. Для належного функціонування УЗВ важливе значення відіграє вид наповнювачів біофільтрів. У біофільтрах зазвичай використовують полімерний наповнювач 3 великою площею поверхні на одиницю об'єму. Бактерії ростуть на наповнювачі, утворюючи тонку плівку з досить значною площею. Проектуючи біофільтр, потрібно враховувати, що площа поверхні його наповнювача на одиницю об’єму має бути якомога більшою, водночас біофільтр не можна наповнювати занадто щільно, оскільки у процесі експлуатації він забивається органічними речовинами. У біофільтрі має бути достатньо простору, щоб уможливити вільне перетікання води (Brajnballe, 2010).

3 метою створення у фільтрі турбуленції для відокремлення органіки від наповнювача в УЗВ використовують стиснуте повітря, яке подається спеціальним пристроєм. При цьому подачу води до біофільтра припиняють. Брудну воду з біофільтра зливають і видаляють перед його повторним підключенням до системи (Asi and Relve, 1985).

Біофільтри УЗВ можуть бути спроектовані як фільтри з плаваючим або нерухомим наповнювачем. Bci біофільтри, нині використовувані у рециркуляції, під час експлуатації повністю занурені у воду. У фільтрах 3 нерухомим наповнювачем полімерні елементи нерухомо скріплено. Вода протікає через нього ламінарним потоком і стикається з бактеріальною плівкою. У фільтрах з плаваючим наповнювачем полімерні елементи рухаються за рахунок нагнітанням повітря всередину біофільтра (Feofanov and Golosuj, 1986; Grigor'ev and Sedova, 2008). За постійного руху наповнювача фільтри 3 плаваючими елементами можуть бути наповнені щільніше, ніж фільтри 3 нерухомими елементами. 3 огляду на це швидкість зміни води на одиницю об'єму має бути більшою для перших. У вітчизняній аквакультурі здебільшого використовують наповнювачі іноземного виробництва, які мають значну робочу поверхню - від 600 до $2300 \mathrm{~m}^{2}$.

Для насищання води киснем у замкнутих установках зазвичай використовують технічний газоподібний кисень. Його подають у воду за допомогою спеціаль- 
них приладів - оксигенаторів. Використання такої техніки задовольняє потреби риби в кисні, а також компенсує його споживання мікрофлорою біологічних фільтрів (Grycynjak et al., 2014).

Швидкість обороту води на одиницю площі біофільтра в УЗВ за використання різних типів наповнювачів приблизно однакова, оскільки ефективність бактеріальної плівки при цьому практично не змінюється. 3 іншого боку, фільтри 3 нерухомим наповнювачем затримують також дрібні органічні речовини, оскільки ті приростають до бактеріальної плівки. Саме тому такі фільтри функціонують також як блоки для тонкої механічної фільтрації, що уможливлює видалення органіки мікроскопічного розміру і досить ефективно очищає воду (Grigor'ev and Sedova, 2008).

У фільтрах 3 рухомим наповнювачем неможливо досягти подібного ефекту, оскільки постійна турбуленція води не дає змоги частинкам затримуватись на поверхні елементів.

У будь-якій системі для вирощування риби можуть використовуватись обидві схеми фільтрації. Вони також можуть комбінуватися.

Огляд джерел літератури показує, що вирощування цінних видів риби перспективне в УЗВ, однак для цього необхідне грамотне технічне проектування та наукове обгрунтування кількості посадженої риби на 1 м $^{3}$. Зокрема, у разі посадки цьоголіток та товарної риби слід враховувати темп росту, що, своєю чергою, залежить від параметрів води. Коли останні дотримуються належним функціонуванням усіх структурних частин УЗВ, ключову роль у результативності роботи господарства на отримання біомаси продукції, закладену під час проектування, відіграватиме годівля. Досягнення рибницьких цілей з переведення вирощуваних об'єктів на екзогенне живлення значною мірою залежить від управління годівлею. Годівля в замкнутих установках - практично єдине джерело корму. Водночас годівля впливає на якість води, що циркулює в установці. На величину раціону впливають вид риби, їі індивідуальна маса, температура та інші параметри води, концентрація кисню, концентрація технічних речовин, освітленість, якість корму. Якщо всі зазначені параметри враховано вірно, раціон буде підібрано оптимально і кормовий коефіцієнт буде мінімальним.

3 огляду на те, що в замкнутих установках існує велика загроза виникнення епізоотій, важливим фактором $є$ можливість проведення профілактичних та лікувальних заходів у системі УЗВ. За вирощування риби в замкнутих установках, особливо за великої густоти їх посадки та інтенсивної годівлі, у воді накопичується багато органічних сполук, якими живляться гетеротрофні бактерії. Останні очищують середовище від органічних забруднень, але водночас $є$ причиною виникнення несприятливої епізоотичної обстановки (Bohdanova et al., 1988).

\section{Висновки}

Таким чином, використання наповнювачів біофільтрів відіграє одну з ключових ролей для підтримання оптимальних умов для роботи УЗВ.
Ветеринарні заходи, у господарствах такого типу, відповідно до встановленого діагнозу варто здійснювати у такий спосіб, щоб, допомагаючи одному організму (райдужна форель), не зашкодити іншому (біоплівка наповнювача фільтраційного реактора). Подальші дослідження варто зосередити на вивченні складу, фізіологічних особливостей та ролі біоплівки як суміжного організму під час вирощування об'єктів аквакультури.

\section{Бібліографічні посилання}

Alabaster, Dzh., Llojd, R. (1984). Kriterii kachestva vody dlja presnovodnyh ryb. M.: Legkaja i pishhevaja promyshlennost' (in Russian).

Asi, A.A., Relve, P.F. (1985). Opredelenie optimal'noj proizvoditel'nosti rybovodnoj ustanovki s zamknutym ciklom vodoobespechenija. Industrial'noe rybovodstvo $\mathrm{V}$ zamknutyh sistemah: sb. nauch. trudov. M. VNIIPRH. 10-14 (in Russian).

Bogdanova, L.A., Perminova, E.B., Puhovskij, A.B., Asarova M.H. (1988). Mineral'nyj sostav vodnoj sredy $\mathrm{v}$ zamknutyh rybovodnyh sistemah. Industrial'noe rybovodstvo $\mathrm{v}$ zamknutih sistemah: sb. nauchn. trudov. M.: Izd-vo VNIIPRH. 18-23 (in Russian).

Zhezmer, V.Ju., Beljakova, N.V. (1988). Mikrobiologicheskie kriterii ocenki jepizootcheskogo sostojanija ustanovok s zamknutym ciklom vodoobespechenija $\mathrm{v}$ otnoshenii ajeromonoza karpa. Industrial'noe rybovodstvo $\mathrm{v}$ zamknutyhsistemah: sb. nauchn.trudov. M. Izd-voVNIIPRH (in Russian).

Labbe, L., Lefevre, F., Bugeon, J., Fostier, A., Jamin, M. (2014). Gaume Rainbow trout farming in Recirculating Aquaculture System (RAS): an innovative and environmental friendly system. INRA Productions Animales. 27(2), 135-145.

Hrustalev, E.I. Izuchenie prikladnyh aspektov v obosnovanii tehnologij regional'noj akvakul'tury / Otchet o NIR. Rukovoditel'. № 01201265034 Kaliningrad: FGBOU VPO «KGTU». (in Russian).

Hrustaljov, E.I., Suslo, A.Je., Elfimova, K.A. (2013). Ocenka jeffektivnosti vyrashhivanija remontnomatochnogo stada raduzhnoj foreli $\mathrm{V}$ ustanovke zamknutogo cikla vodoobespechenija. Innovacionnye tehnologii $\mathrm{V}$ pishhevoj promyshlennosti: nauka, obrazovanie i proizvodstvo: mezhdunar. nauch.-tehn. konf. (zaochnaja): materialy (3-4 dek.). Voronezh. 149-154 (in Russian).

Titarev, E.F. (2005). Holodnovodnoe forelevoe hozjajstvo. Rybnoe h-vo (in Russian).

Ponomarev, S.V. (2009). Osetrovodstvo na intensivnoj osnove. Moskva: Kolos (in Russian).

Kupinskij, S.B. (2007). Produkcionnye vozmozhnosti obektov akvakul'tury. Astrahan': Izd-vo DF FGOU VPO «AGTU» (in Russian).

Matishov, G.G., Matishov, D.G., Ponomareva, E.H. i dr. (2006). Opyt vyrashhivanija osetrovyh ryb v uslovijah zamknutoj sistemy vodoobespechenija dlja fermerskih hazjajstv. Rostov-na-Donu: Izd-vo JuNC RAN (in Russian).

Novozhenin, N.P., Filatov, V.I., Petrov F.A. i dr. (1985). Rybovodno-biologicheskie normativy po 
vyrashhivaniju karpa, foreli $\mathrm{v}$ ustanovkah $\mathrm{s}$ zamknutym ciklom vodosnabzhenija. M.: Izd-vo VNIIPRH. 16 (in Russian).

Ojsbojt, M.I. (1985). Primenenie lechebnyh obrabotok protiv jentoparazitnoj jenvazii lichinki karpa $\mathrm{V}$ ustanovke $\mathrm{s}$ zamknutym tipom vodosnabzhenija. Industrial'noe rybovodstvo v zamknutyh sistemah: sb. nauchn. trudov. M.: Izd-vo VNIIPRH (in Russian).

OST 15.372-87. Ohrana prirody. Gidrosfera. Voda dlja rybovodnyh hozjajstv. Obshhie trebovanija i normy (Vstupil v dejstvie: s 01.04.88). M. 18 (in Russian).

Proskurenko, I.V. (2003). Zamknutye rybovodnye ustanovki. M.: Izdatel'stvo VNIRO (in Russian).

Feofanov, Ju.A., Golosuj, V.P. (1986). K vyboru metodov ochistki oborotnoj vody industrial'nyh rybovodnyh hozjajstv s zamknutym ciklom vodoispol'zovanija. Tehnicheskie sredstva marikul'tury: sb. nauchn. trudov. M.: Izd--vo VNIRO. 152-158 (in Russian).

Brajnballe, Ja. (2010). Rukovodstvo po akvakul'ture v ustanovkah zamknutogo vodosnabzhenija. Vvedenie v novye jekologicheskie i vysokoproduktivnye zamknutye rybovodnye sistemy. Kopengagen. 70 (in Russian).

Grigor'ev, S.S., Sedova N.A. (2008). Industrial'noe rybovodstvo. Chast' 1. Biologicheskie osnovy i osnovnye napravlennja razvedenija ryby industrial'nymi metodami: Uchebnoe posobie. Petropavlovsk Kamchatskij: KamchatGTU (in Russian).

Grycynjak, I.I., Tretjak, O.M., Kolos, O.M. (2014). Istorychni aspekty, stan ta perspektyvy rozvytku rybogospodars'koi' dijal'nosti na vnutrishnih vodojmah Ukrai'ny. Visnyk Sums'kogo nacional'nogo agrarnogo universytetu: Serija «Tvarynnyctvo». 2/1(24), 22-29 (in Ukrainian).

Bohdanova, L.A., Permynova, E.B., Pukhovskyi, A.B., Asarova, M.Kh. (1988). Myneralnyi sostav vodnoi sredy V zamknutykh rybovodnykh systemakh Yndustryalnoe rybovodstvo v zamknutykh systemakh: sb. nauchn.trudov. M.: Yzd-vo (in Russian).

Стаття надійшла до редакиії 10.09.2016 